\title{
SYSTEM MANAGEMENT OF INTERNAL QUALITY ASSURANCE FOR COLLEGE AT THE UNIVERSITY OF ISLAM BALITAR BLITAR INDONESIA
}

\author{
Anang Dwi Putransu Aspranawa \\ Postgraduated Education Management Program, \\ University State of Malang, Indonesia \\ adp_aspranawa@yahoo.com
}

\author{
Dyah Pravitasari \\ Postgraduated Education Management Program, \\ University State of Malang, Indonesia \\ dyah_pravitasari@yahoo.com
}

\begin{abstract}
Quality assurance is the process of determining and fulfilling quality standards with consistent, systematic and sustainable management, to meet the needs of internal stakeholders and external stakeholders. Universities are qualified if they are able to realize their vision through the implementation of their mission, and able to meet the needs of the stakeholders. In other words, ideally, the implementation of university quality assurance is to maintain the quality of education. This applies to the University of Islam Balitar, as a university that has run the internal quality assurance system, is still not optimal. This is caused by several factors, namely the lack of understanding about the importance of cvitas academica about quality assurance for the continuity of universities. The active role of the academic community associated with quality assurance still minimal. Based on that case, it is necessary to study the internal quality assurance system at the University of Islami Balitar in order to realize the quality culture. The focus of the study is to be limited to: (1) elements of internal quality assurance; and (2) how the implementation of internal quality assurance at the University ofIslam Balitar. The purpose of this study is to describe about: (1) Elements of internal quality assurance management of the College atthe University ofIslam Balitar, Blitar; and (2) Implementation of internal quality assurance the University of Islam Balitar Blitar. The research used qualitative approach with research type of field study. The location of the research was conducted at the University of Islam Balitar Blitar. The source of data used is to emphasize the person as an informant. Data collection techniques using observation, interview and documentation. The result of research that elements of quality assurance at the University of Islam University still focus on academic quality assurance system, quality assurance system does not cover quality assurance of research field and community service field. Implementation of quality assurance using PDCA system that is, Plan, Do, Check, and Action.
\end{abstract}

Keywords: system, management, quality assurance, quality standard, andinternal audit.

\section{A. Background Issues}

\section{INTRODUCTION}

The world of education both formal education and non-formal education is one of the containers for the process of forming and nurturing the expertise, skills demanded must be quality and/or qualified, both in terms of functionality side internal and external utility. [14] "Internal quality is based on compliance with external specifications and qualities based on perceived from the customers." Things that can be the basic for the organizers, educational managers of something of a quality-qualified are measured from the perspective of users, coustomers and stakeholders.

The unsuccessful management of the universities in realizing quality education will result in the unwillingness of graduates to actualize themselves as scholars in the midst of society, also explained in the dissertation on the quality of higher education in Hong Kong by [3]. It was found that: "the quality of education is a reaction to a number of related state changes". [7] the emergence of quality improvement due to the lack of ability of graduates in entering the world of work". For that reason college is expected to increase the capacity of self through strengthening the governance of quality assurance system that can be done refinement and continuous development.In a system whose implementation is realized through the activity of management, stewardship or more precisely called applying quality assurance management system of education is well ordered in the sense of conformity to the established standard of education quality.
The quality assurance of universities is ideally intended to maintain the quality of education, the implications for each university are not the same between one institution and another. The difference is according to [4]: "highly dependent and influenced by the sensitivity of the college concerned to the perception of the marketization and consumerism of the universities concerned as well as the purpose and function of the quality assurance being running out". [10] affirms that the implementation of quality assurance is relative and diverse so that the range of quality assurance implementation is different from each other, [5] Although the range of quality assurance is very diverse, essentially always consisting of: executor (lecturer) and process.

Consider of the education's matter that appear so complex requires serious thinking, therefore the implementation of higher education needs the role of internal quality assurance that can not be viewed with one eye. The quality of the university is good if the internal quality assurance system works well. Similarly, colleges that make problems with the withdrawal of the license of the study program even disabled for operate, because the result of one of the internal quality assurance management system of universitiesnot running well. Higher education in universities is considered qualified if able to realize its vision through the implementation of its mission, and able to meet the needs of stakeholders, in the form of societal needs, industrial needs, professional needs [6]. 


\section{B. Literature Review}

1) The Quality Concept

The simple understanding of the definition from "Quality" can be interpreted: according to standards, as perexpectations, in accordance with the agreement 'as required, and so on. To ascertain the meaning of quality it is better to know in advance the origin of the word quality which is etymologically derived from the Latin "Qualis" which means "what kind of" in the sense of quality has a varied meaning. For more complete and ethical besides the above statement in quotation some opinions of quality meanings.

According Jay Schlickman, 2003:19; "Quality is something that is not absolute but more to what is acceptable from the customer side," According to [11] "Quality is a match with the product", Goetsch and Davis (1994) define the quality of a dynamic condition associated with service products, humans, processes and environments that meet or exceed expectations. ISO 9000: 2000 in [9] explain "quality is the ability of a series of characteristics that the product has to meet the requirements/ needs".

From some opinions if in the analysis there are 2 (two) aspects, first in accordance with the specifications and/ or predefined standards. Second, the fullfill of the needs of products/ services to users. So it can be mentioned that quality is the result of a production process in the form of goods and / or services in accordance with predetermined standards. The application of quality the education, especially in the environment of higher education is the level of conformity between the implementation of higher education with higher education standar has been set.

\section{2) Quality Assurance}

Ensure that all the characteristics and performance in accordance with the standards/ expectations/ requirements are called Quality Assurance. To complete the description, cited several opinions according to [8]:"Quality assurance is all the systematic plans and actions necessary to provide the trust used for satisfying a particular need". According to Gryna (1988):"quality assurance is an activity to provide evidence to build trust that quality can function effectively". Clarified [2] "Quality Assurance is all planned and systematic activities imposed in the quality system that can be demonstrated to provide confidence that a product or service will fulfill requirements for quality".

Based on several definitions it can be understood that the meaning of quality assurance there are 2 (two) point of view as which as mentioned in the guidebook of quality assurance of university that is "First; The meaning of general quality assurance is the process of stipulating and fulfilling quality standards with consistent, systematic and sustainable management, so that consumers, producers, and other interested parties obtain satisfaction and confidence in the products offered. Second,the meaning of special quality assurance in the environment of higher education is the process of planning, determining, controlling and developing quality standard of management of higher education consistently and continuously, so that internal stakeholders (students, lecturers and employees) and external (societies, business, professional association, goverment) from universities get satisfaction "(Directorate of Academic of Higher Education, 2009).

\section{3) Quality Assurance System of Higher Education}

Explain at article 55 Law's Dikti systematic activities to raise the quality of higher education on a planned and sustainable basis is called the Higher Education Quality Assurance System, its application to each university based on the college quality assurance guideline [12]. The Mechanism of Dikti Quality Assurance System begins by universities by implementing SPMI through the cycle of activities that form a cycle abbreviated as PPEPP in Indonesia's languange, is described as follows:

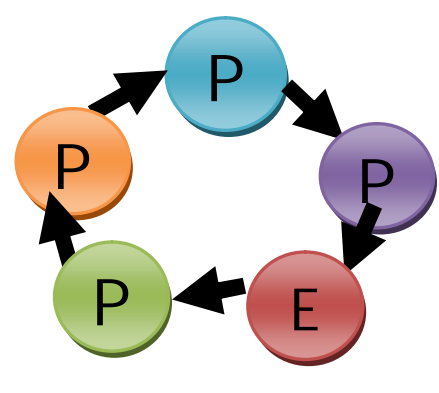

Picture 1

Cycle of Quality Assurance System

PPEPP in Indonesia's languageare:

$\mathrm{P}=$ Penetapan Standar Pendidikan Tinggi

$\mathrm{P}=$ Pelaksanaan Standar Pendidikan Tinggi

$\mathrm{E}=$ EvaluasiStandar Pendidikan Tinggi

$\mathrm{P}=$ Pengendalian Standar Pendidikan Tinggi

$\mathrm{P}=$ Peningkatan Standar Pendidikan Tinggi

Information:

1) Penetapan (P) DIKTI Standard, which is standard setting activity consisting of National Standard Dikti and Guidance of quality system of Higher Education of Higher Education of Higher Education Standard stipulated by university;

2) Pelaksanaan (P) Standards of Higher Education, namely the fulfillment of standards consisting of National Standard Dikti and Standard of Higher Education stipulated by universities;

3) Evaluation (E) of the implementation of the Higher Education Standard, which is comparative activity between the output of standard fulfillment activities with the standard consisting of SN Dikti and Dikti standard set by the university;

4) Pengendalian (P) implementation of the Higher Education Standard, which is the standard cause analysis activity consisting of National Standard Dikti and Dikti Standard set by universities that are not achieved for corrective action; and

5) Peningkatan $(\mathrm{P})$ Standard of Higher Education, which is standard improvement activity consisting of National Standard Dikti and Dikti Standard to be higher than standard consisting of National Standard Dikti and Standard Dikti that have been set. 
Structure of Quality Assurance System of Higher Education (SPM-PT) based on Permendikbud Nomor50 year 2014 is classified into 3 (three) arrangements: First, Internal Quality Assurance System (SPMI): that is systemic activity of quality assurance of higher education by each university autonomously or independently to control and improve the organization of higher education on a planned and sustainable basis; Second, External Quality Assurance System (SPME) is an assessment activity through accreditation to determine the feasibility of study program and college:"Third Database of Higher Education (PD Dikti), which is data collection and information of higher education of all universities in Indonesia which is integrated nationally .

4) Quality Management System of Higher Education Quality Assurance Management System is an action embodiment assure the activities of the process of implementation and qualityresults. Quality Assurance Management System of education includes education input, education process, educational output and educational outcome. In a sense input, high quality education quality expressed by its meaning when it is in readiness for the activities of the learning process, educational process expressedby meaning-grade quality when in the implementation of effective and efficient learning activities, as well as the output is expressed by meaning-quality grade when the graduates of education provision. Acceptable in the world of work and/ or used for the fulfillment of interests. The following description of the quality management system of higher education in which there are elements and/ or basic functions of supporting higher education and the implementation on grain quality of higher education.

Efforts to improve the quality of education can not be separated by the quality of education management. In quality management, all management functions undertaken by education management actors are directed to provide satisfaction to their customers, especially to external customers/ stakeholders. In order to provide satisfaction to the customer, a certain guideline or standard is required as a criteria, and the educational services provided must conform to the established standards; all education management functions are directed to ensure that all educational services provided at least meet customer expectations and / or who are interested.

\section{5) Quality Control Management}

Management quality control is an activity that aligns with quality improvement efforts to make it better. The term qualityis defined as an adjustment to the expectations, standards, procedures that have been established to meet internal and external needs.To maintain the quality of applied quality control and quality assurance. While quality assurance is a system designed to establish quality standards and meet the needs of stakeholders.

Quality control management prioritizes satisfaction for users and stakeholders. The emphasis is on continuous improvement efforts. In theory Total quality management (TQM) is an expanded quality assurance with a customer-focused integrated effort.

\section{Research Purposes}

The purpose of this research is to describe internal quality assurance management system of The University of Islam Balitar Blitar, include:

1. Elements of internal quality assurance management Higher Education The University of Islam Balitar Blitar;

2. Implementation of internal quality assurance The University of Islam Balitar Blitar.

\section{METHODS}

The approach of this research is qualitative, and the type is field research.The location of the research at The University of Islam Balitar includes characteristics, elemental values and factors associated with the system of quality assurance of higher education by descriptive study method. The source of data in this case according [1] divide data into three groups: (1) person, (2) place, and (3) paper. This research use source data in the form of person or respondent as informan.

According to Moeleong: "to determine the informants in this study using techniques and specific purposes (purposive sampling), by snow ball is to keep the data needed to answer the questions. Data collection, conducted with observation, interview, and documentation, The data analysis uses interactive model analysis consisting of three activities, namely; data reduction, data presentation, and conclusion/ verification. The analysis of this Interactive Model is based on the ideas of Miles and Huberman (1992).

\section{OUTCOME \\ A. Elements of Internal Quality Assurance Management of Higher Education Univertas Islam Balitar Blitar}

The University of Islam Balitar Blitar conducts quality education with the implementation of internal and/or self-sustained programmed and continuous internal quality assurance activities. Internal Quality Assurance Management Islamic Higher Education The University of Islam Balitar is based on 2 (two) documents, they are (1) Academic documents contains: direction/policy, vision-mission, education standard, research, and community service, and Academic Guideline which contains: academic regulations, learning achievements, graduate competencies, learning outcome. (2) Quality document: as an instrument to achieve and meet the established standard, substance the quality document shall consist of quality policy, procedure manual, work instruction, and supporting document.

To support the implementation from the quality assurance of higher education forachieveto the continuous quality of education and development, The University of Islam Balitar Blitar runs a quality assurance cycle model by using Plan, Do, Check, Action (PDCA). This cycle is the realization of quality assurance program of control management model (2) Implementation of education Quality Standards, (3) 
Evaluation of the implementation of Education Quality Standards, (4) Implementation Control, Education Quality Standards, and (5) Improvement of Quality Assurance Standards Education Quality Standards.

\section{B. Implementation of internal quality assurance The University of Islam Balitar}

The University of Islam Balitar performs activities in the context of continuous internal quality assurance which continuous improvement running the quality assurance cycle models by using Plan, Do, Check, Action (PDCA) implementation as follows:

1. Determination of Quality Standards (Plan)

Generally, what is meant by quality assurance is the process of determining and meeting management standards consistently and continuously so that stakeholders get satisfaction. Colleges have the autonomy to choose, formulate and set their own quality standards that will be used as guidelines. Higher Education Quality Standards used as a basic guidance implementation the processof higher education, in context internal quality assurance system established by the Government through Minister of Research and Technology of Higher Education or other institutions which is affirmed, and there is Higher education quality standards are regulatedby nongovernmental in the form of quality standards educator from abroad.

The stipulation of the education quality standard of The University of Islam Balitar refers to the Regulation of the Minister of Research and Technology of Higher Education the Republic of Indonesia Number 44 year 2015 on national standards including Education Standards, Research Standards and Standards of Community Service.

\section{Implementation of Education Quality Standards} (Do)

Implementation of education quality standard of The University of Islam Balitar aims to meet or realize the implementation of quality education and/ or quality. Shall be conducted by internal quality assurance system of the universities themselves which are carried out in stages starting from Institution (University), Faculty (implementation in the department/ study program) to ensure compliance to quality policy, quality standard and quality objectives.

The University of Islam Balitar has run academic quality standard of education in the field of:

a) The Recruitment Standard of new student: Institution through team the new admissions committee formulates the selection of new student candidates in each academic year, based on the institution's acceptance target indicating that the side in order to implement that standards is the new admissions committee;

b) Standards of Scheduling prelection: The Dean makes prelection's plans in each semester based on the needs of the courses proposed chief of departement, showing that the side that must implement the standard is the Dean and Chief of Departement c) Learning Standards: 'The lecturer prepares the semester learning plan of the course that they teach and distributes to the all their students, during the first meet at the class at the beginning of each semester', the lecturer which mustimplement that standard;

d) Standard of Mid Semester Test and Final Exam: Lecturers prepare the test script to be submitted to the examination team at the end of the semester which must implement the standard is the lecturer;

e) Standard of KKN implementation: head of LPPM prepares the implementation plan of $\mathrm{KKN}$ as the embodiment of Tri Dharma of higher education to be submitted to the Rector and Dean as a notification that must implement the standards are Rector, Head of LPPM, Dean, and others.

3. Evaluation of Higher Education Quality Standards. (Check)

The evaluation of the implementation at quality standard of higher education the University of Islam Balitar Blitar implemented systematically by collecting and processing data from the implementation of standard quality of education that has been established. The purpose of evaluation to know the quality improvement of education that is run, the usage as the basic framework of the formulation of improvement and quality control of education.

The evaluation of the quality standard from education within the framework of escorting the learning process activities at the University ofIslam Balitar Blitar includes education/ teaching, research and community service in fulfilling the quality standard of education, conducted evaluation is the self-evaluation of education unit performance.The self-evaluation conducted by the University ofIslam Balitar Blitar there are 8 (eight) steps as follows:

1. Preparation for self evaluation conducted by the Chief of Departement as a coordinator is assisted by lecturers and staff of education.

2. Issuance of Letter of duty from the Head of Education Unit.

3. Implementation of goal setting and self-evaluation coverage as well as the work plan and schedule of implementation.

4. Collection of information/ primary and secondary data match coverage of self evaluation.

5. Implement data analysis in accordance with the standard quality of education that has been established by using SWOT analysis.

6. Exposure of self-evaluation results to all members of education Unit for clarification and refinement of self-evaluation documents.

7. Submission of self-evaluation documents to education unit leaders for policy advice.

8. The activities evaluation ended with the endorsement of documents by the head of the educational unit.

\section{Quality Standards Control (Check)}

Quality control is performed by Badan Penjaminan Mutu (BPM) the University of Islam Balitar Blitar by conducting monitoring and Internal 
Quality Audit (AMI). The operationally in the form of a questionnaire (circulating quisioner) and monitor directly in the field. Implementation Internal monitoring (monevin) is conducted continuously at the faculty and/ or department level in the beginning and middle of semester, the scope covers are: lectures, academic supervision, thesis supervision, semester exam, thesis examination, judicial and quality procedures.

To Control of quality standards in Audit activities there are 2 (two) types, they are: internal auditquality and external audit quality. Internal auditquality is establishing Internal Audit Team with Rector's Decree. The operational activity is in the form of a questionnaire (to circulate quisioners) to the Manager and Academic Executor (structural staff except the Rector, and lecturers functional staff) conducted periodically at the end of each semester in each academic year and the activities are grouped into 2 (two) types of audit activities: (1) Audit of academic areas such as: Audit of learning process activities include completeness of lecturers teaching preparation, lecturer performance audit in learning include: Measuring student satisfaction level to academic service, Audit performance in achieving quality objectives. (2) Non-academic audits include: audit performance supporting units of academic implementation.

External Audit quality at the University ofIslam Balitar Blitar is conducted by independent external organizational units such as the State Accreditation Board of Higher Education (BAN-PT) or other organizations. Implementation of External Quality Audit Activities shall be conducted on courses or Institutions for the development or improvement of the quality of continuing education.

\section{Continuous improvement and development (Action)}

Continuous improvement and development in the context of improving the standards to be achieved, in general is a continuous approach (measuring the achievement results against established quality standards). The University of Islam Balitar Blitar performs improvements and development in achieving the established quality standard, continuous improvement, 3 (three) guiding principles in the process of continuous improvement and development: (1) outcome monitor condition (self evaluation), (2) (target), (3) quality achievement (action plan).

\section{DISCUSSION}

The University of Islam Balitar Blitar conducts internal assurance of internal quality regulated integrally from education and teaching, to research and community service. The continuous improvement the quality of education in the sense that the University of Islam Balitar sets education standards quality, running the quality standards of education, evaluates the implementation of quality standards of education, to controls the implementation of education quality standards and arrise the quality of education standards its them self.
Elements of internal quality assurance management Higher Education The University of Islam Balitar, as a means of supporting the activities of achieving continuous quality objectives (continuous improvement), running quality assurance cycle model using Plan, Do, Check, Action (PDCA). (2) Implementation of Education Quality Standards, (3) Evaluation of Education Quality Standards, (4) Implementation Control, Quality of Education Standards, and (5) Improvement of Education Quality Standards.

Implementation of internal quality assurance the Unversity of Islam Balitar Blitar, earlierrunning activities carried out the preparation of 2 (two) Internal Management Assurance System or we use called SPMI in Indonesia's languange. The documents include: (1) academic documents, document subtansi: visionmission, policy, implementation standards from TriDharma College, Academic guidelines. (2) Quality document such as: document substance: quality policy, procedure manual, work instructions, and supporting documents, further document contents and evaluate the implementation and enhancement which is the realization of the contents of the quality document. The Implementation of Higher Education Quality Standards as follows:

\section{A. Determination of quality standards (Plan)}

The stipulation of the education standard quality the University of Islam Balitar Blitar refers to the Regulation of the Minister of Research and Technology of Higher Education of the Republic of Indonesia Number 44 year 2015 on national standards including three bigest standar, they are: Education Standards, Research Standards and Standards of Community Service.

\section{B. Implementation of Education Quality Standards (Do)}

The University of Islam Balitar Blitar has run the academic quality standard of education in the field of: (1) Standard Recruitmentfor new students: (2) Standard Scheduling Lectures: (3) Standard Learning: (4) Standard examination like Mid test and final test, (5) Standard implementation of KKN, etc.

\section{Evaluation of Higher Education Quality Standards. (Check)}

Evaluation of standard quality the education at the University of Islam Balitar Blitar includes the implementation of Tri Dharma of Higher Education for fulfillment standard of education quality, evaluation is self evaluation of education unit performance, by following procedure: (1) Preparation of self evaluation by Chief of Departement, (2) Data Analysisin accordance with the quality standard with SWOT analysis, (3) Exposure of self evaluation results, (4) Submission of documents self-evaluation results, and (5) Ended with the endorsement of the document by the head of the educational units.

\section{Quality Standards Control (Check)}

Quality control is performed by Quality Assurance Agency or we called Badan Penjaminan 
Mutu in Indonesia's languange the University of Islam Balitar Blitar by conducting monitoring and Internal Quality Audit (AMI). The operational form a questionnaire (circulating quisioner) and monitor directly in the field. Implementation Internal monitoring (monevin) in the faculty and/ or the department of study was running, the scope covers the implementation: lectures, academic counseling, tutoring thesis, examination, thesis examination, judicial and quality procedures. Audit implementation there are 2 (two) Internal Quality Audit and External Quality Audit, Internal Quality Audit (AMI) is establishing an Internal Audit Team with Rector's Decree. The activities in the form of a questionnaire (circulating quisioner) to the Manager and Academic Executives (structural personnel except the Rector, and functional staff of lecturers) and its activities are grouped into 2 (two) types of audit activities: (1) academic audit, and (2) non-academic audit. External Quality Audit at the University of IslamiBalitar Blitar is conducted by independent external organizational units such as the State Accreditation Board of Higher Education (BANPT) or other organizations.

\section{E. Continuous improvement and development (Action)}

Continuous improvement and development in the context of improving the standards to be achieved, in general is a continuous approach (measuring the achievement results against established quality standards).The University of Islam Balitar Blitar performs improvements and development in achieving the established quality standard, continuous improvement, 3 (three) guiding principles in the process of continuous improvement and development: (1) outcome monitor condition (self evaluation); (2) (target); and (3) quality achievement (action plan).

\section{CONCLUSION}

Based on the research that has been done, it can be concluded that the implementation of the internal quality assurance system at the University ofIslam Balitar, still running the PDCA system, that are Plan Do Check and Action. Internal quality assurance activities are carried out by conducting internal and external audits. Internal audits are conducted periodically at the end of each semester by distributing questionnaires to all ciitas academicia. The audits are still limited to the academic audit which includes Tri Dharma Higher Education activities consisting of education and teaching, research and community service. External audit conducted by the Universitas of Islam Balitar is to follow the audit stipulated by BAN-PT through its assessment standards.

\section{ACKNOWLEDGEMENT}

Praise God for the presence of Allah SWT over the abundance of rahmad and karuan for writers so that can finish this article. Especially many thanksthe witer expressed to:

1. Kemenristek Dikti for financial support so it can be finish this article.
2. Prof. Dr. I Nyoman Sudana Degeng, M.Pd as the director of Post Graduate The State University of Malang.

3. Prof. Dr. H. Bambang Budi Wiyono, M.Pd as the first dissertation promoter.

4. Prof. Dr. H. Ali Imron, M.Pd, M. Si as second dissertation promoter.

5. Prof. Dr. H.M. Huda AY, M.Pd as the third dissertation promoter.

6. All people who have assisted in the completion of this article.

\section{REFERENCE}

[1] Arikunto, S. 2013. Prosedur Penelitian Suatu Pendekatan Praktik. Jakarta: Rineka Cipta.

[2] Cartin T. J. 1999. Priciple and Practise of Organizational Performance Excellen. London: MacGraw Hill.

[3] Cecelia T. 2002. Quality in Higher Education: Policies and Practices a Perspective Introduction and research Approach. Dissertation. Hongkong.

[4] Damme, V. D. 2002. Trend and Models In International Quality Assuranceand Accreditation in Higher education, In Relation to Trade in Educatio Services. Washington D.C.: US Forum on Trade in Educational Services.

[5] Degeng, I. S. 1997. Strategi Pembelajaran, Mengorganisasi Isi dengan Model Elaborasi. Malang: Ikatan Profesi Teknologi Pendidikan Indonesia.

[6] Ditjen Dikti. 2003. Pedoman Penjaminan Mutu Pendidikan Tinggi. Jakarta: Direktorat Jenderal Pendidikan Tinggi, Departemen Pendidikan Nasional.

[7] Earnest, J. 2001. Competency-Based Engineering Curriculum, AnInnovative Approach. Oslo: International Conference on Engineering Education. August 6-10.

[8] Elliot. 1993. Management of Quality in Computing Systems Education: ISO 9000 series Quality Standards Applied. Journal of System Management, September, 6-11.

[9] Hoyle, D. 2007. ISO 9000 Quality System Handbook. Great Britain.

[10] Jackson, N. 1998 Understanding Standard Based Qualitative Assurance Part II, Nuts Bolts of Dearing Policy Work. Qualitative Assurance in Education, Vol 6.

[11] Juran, J. M., and Godfre, A .B. 1999. Juran Quality Handbook. New York: Mac-Grow Hill.

[12] Kementerian Riset, Teknologi, dan Pendidikan Tinggi, Dikrektorat Jenderal Pembelajaran dan Kemahasiswaan. 2016. Pedoman Sistem Penjaminan Mutu Pedidikan Tinggi. Jakarta: Direktorat Penjaminan Mutu, Kementerian Riset, Teknologi, dan Pendidikan Tinggi.

[13] Moleong, L. J. 2013. Metode Penelitian Kualitatif. Bandung: PT Remaja Rosdakarya.

[14] Payne, A. 2000. The Essence of Service Marketing. Yogyakarta: Penerbit Andi.

[15] Peraturan Menteri Riset, Teknologi, dan Pendidikan Tinggi Republik Indonesia, No. 44 tahun 2015, tentang Standar Nasional Pendidikan Tinggi. Jakarta: Kementerian Riset, Teknologi, dan Pendidikan Tinggi.

[16] Schlickman, J. J. 2003. ISO 9001:2000. Quality Management System Design. New York: Artech House. 